\title{
Update on Thiamine Triphosphorylated Derivatives and Metabolizing Enzymatic Complexes
}

\author{
Lucien Bettendorff $\mathbb{C}$
}

check for

updates

Citation: Bettendorff, L. Update on Thiamine Triphosphorylated Derivatives and Metabolizing Enzymatic Complexes. Biomolecules 2021, 11, 1645. https://doi.org/ 10.3390/biom 11111645

Academic Editor: Victoria Bunik

Received: 14 October 2021

Accepted: 6 November 2021

Published: 7 November 2021

Publisher's Note: MDPI stays neutral with regard to jurisdictional claims in published maps and institutional affiliations.

Copyright: (C) 2021 by the author. Licensee MDPI, Basel, Switzerland. This article is an open access article distributed under the terms and conditions of the Creative Commons Attribution (CC BY) license (https:/ / creativecommons.org/licenses/by/ $4.0 /)$.
Laboratory of Neurophysiology, GIGA Neurosciences, University of Liège, 4000 Liège, Belgium; L.Bettendorff@uliege.be; Tel.: +32-4-366-5967

\begin{abstract}
While the cellular functions of the coenzyme thiamine (vitamin B1) diphosphate (ThDP) are well characterized, the triphosphorylated thiamine derivatives, thiamine triphosphate (ThTP) and adenosine thiamine triphosphate (AThTP), still represent an intriguing mystery. They are present, generally in small amounts, in nearly all organisms, bacteria, fungi, plants, and animals. The synthesis of ThTP seems to require ATP synthase by a mechanism similar to ATP synthesis. In E. coli, ThTP is synthesized during amino acid starvation, while in plants, its synthesis is dependent on photosynthetic processes. In E. coli, ThTP synthesis probably requires oxidation of pyruvate and may play a role at the interface between energy and amino acid metabolism. In animal cells, no mechanism of regulation is known. Cytosolic ThTP levels are controlled by a highly specific cytosolic thiamine triphosphatase (ThTPase), coded by thtpa, and belonging to the ubiquitous family of the triphosphate tunnel metalloenzymes (TTMs). While members of this protein family are found in nearly all living organisms, where they bind organic and inorganic triphosphates, ThTPase activity seems to be restricted to animals. In mammals, THTPA is ubiquitously expressed with probable post-transcriptional regulation. Much less is known about the recently discovered AThTP. In E. coli, AThTP is synthesized by a high molecular weight protein complex from ThDP and ATP or ADP in response to energy stress. A better understanding of these two thiamine derivatives will require the use of transgenic models.
\end{abstract}

Keywords: thiamine triphosphate; adenosine thiamine triphosphate; thiamine triphosphatase; adenylate kinase; CYTH; triphosphate tunnel metalloenzymes; thiamine diphosphokinase; ATP synthase; thiamine diphosphate; glutamate dehydrogenase

\section{Introduction}

Thiamine (vitamin B1) is the precursor for thiamine diphosphate (ThDP), an essential coenzyme for many enzymatic reactions in prokaryotes and eukaryotes [1-3] (Figure 1). In animals, the main ThDP-dependent enzymes are the E1 subunits of 2-oxoacid (in particular, pyruvate and oxoglutarate) dehydrogenase complexes and transketolase [4]. These enzymes are essential in oxidative glucose metabolism, explaining why thiamine deficiency leads to severe lesions in particular in tissues with a high oxidative metabolism, such as brain and heart [5]. Thiamine deficiency disorders are still very common, especially in developing countries, and often go unnoticed, resulting in fatal outcome [6-8]. It is beyond doubt that the vast majority of the observed symptoms are due to a decreased oxidative metabolism in the nervous system and the heart due to decreased ThDP coenzyme function. Nevertheless, already in the 1950s and 1960s, the idea of a non-coenzyme role of thiamine or some thiamine derivative took shape, probably as a consequence of two observations:

1. Thiamine deficiency leads to selective brain lesions, the diencephalon being the most affected [9,10];

2. Thiamine was reported to be released during electrical nerve stimulation [11]. 
Considering the now known complexity of the mammalian brain, the first observation might not be so surprising, but it still remains to be explained. Concerning the second observation, a careful review of the literature suggests that many older observations must be taken with care, because of a lack of reliable analytical methods available in these days [12]. Nevertheless, the hypothesis of thiamine non-coenzyme roles continues to be explored in particular in relation to metabolic regulations $[13,14]$. Indeed, it is now well established that besides ThDP, at least two triphosphorylated thiamine derivatives (Figure 1), thiamine triphosphate (ThTP) and the newly discovered adenosine thiamine triphosphate (AThTP), exist in most prokaryotic and eukaryotic cells [15-17], where they might have physiological roles. Moreover, in mammals, ThTP is hydrolyzed by a very specific 25-kDA thiamine triphosphatase (ThTPase, EC 3.6.1.28), coded by the gene thtpa. We will refer to this enzyme as THTPA and use the more general term ThTPase for the enzyme activity.

The aim of the present review is to discuss new data obtained on ThTP, AThTP, and their metabolizing enzymatic complexes (Figure 1).

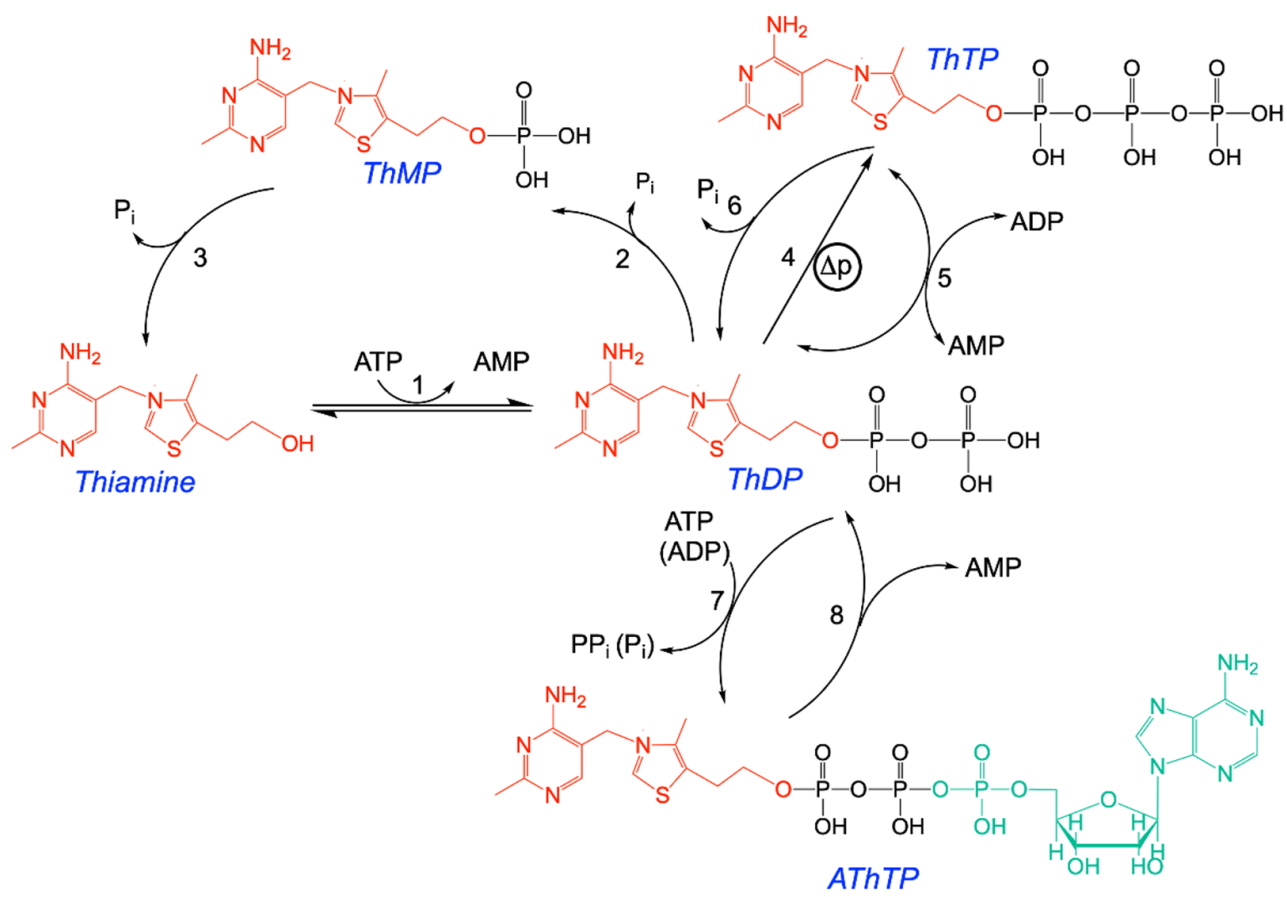

Figure 1. Structural formulas of thiamine and its major derivatives. ThDP is synthesized from thiamine and ATP by thiamine pyrophosphokinase (1). Hydrolysis of ThDP by thiamine pyrophosphatases (2) yields ThMP, which in turn can be hydrolyzed to thiamine by thiamine monophosphatases (3). ThDP can be phosphorylated to ThTP by two mechanisms: mitochondrial ATP synthase (4) and cytosolic adenylate kinase (5). ThTP can be hydrolyzed to ThDP by a very specific cytosolic 25-kDa thiamine triphosphatase (THTPA) but also by other hydrolases (6). ThDP can also be converted to AThTP by a ThDP adenylyl transferase (7). AThTP can be hydrolyzed to ThDP and AMP by a putative AThTP hydrolase (8). Another adenylated thiamine derivative, adenosine thiamine diphosphate (AThDP), not represented here, has been shown to exist in prokaryotes and eukaryotes, but its mechanism of synthesis has not yet been demonstrated in vitro. $\mathrm{P}_{\mathrm{i}}$, inorganic phosphate; $\mathrm{PP}_{\mathrm{i}}$, inorganic pyrophosphate; $\Delta \mathrm{p}$, proton gradient (adapted from [18]).

\section{Thiamine Triphosphate: Occurrence, Synthesis, Regulation, and Role}

\subsection{Occurrence of ThTP in Living Organisms}

The first reports on the existence of ThTP date back to the 1950s in rat liver [19], baker's yeast [20], rat brain [21], and bacteria [22]. Though the existence of ThTP in these tissues was later confirmed, quantitative aspects should be taken with care as reliable methods for 
the determination of ThTP became available only in the 1980s with the advent of highly selective and sensitive HPLC methods (for a discussion of this point, see [16,23]). It is also possible that in some cases, ThTP was confounded with AThTP, discovered much later [17]. With state of the art methods, ThTP could be detected, often in highly variable amounts, in practically all animal tissues, plants, fungi, and bacteria [15].

In animal tissues, ThTP is constitutionally present in very variable amounts, reflecting tissue-specific balances between synthesis and hydrolysis. In the rat brain, the turnover of ThTP is relatively low with a half-life of $1-2 \mathrm{~h}[24,25]$. In 2010 , we published a vast study on the occurrence of ThTP and AThTP in human biopsies [26]. ThTP was found in practically all tissues tested, including all major organs and systems, in the range of less than $1 \%$ to over $20 \%$ of total thiamine. ThTP levels were generally higher in human compared to the corresponding rodent tissues, which is probably due to the less active 25-kDa ThTPase, an important regulator of ThTP levels in animals (see below). While in the brain, ThTP is mainly localized in mitochondria and mitochondria-rich fractions (synaptosomes), in skeletal muscle and liver, it is mainly in the cytosolic fraction, most probably reflecting different mechanisms of synthesis (see Section 2.2) [25-27].

On the other hand, in E. coli, it has to be induced by a carbon source in amino aciddeficient media and can rapidly reach up to $50 \%$ of total thiamine $[28,29]$. As ThTP synthesis in E. coli only occurs in a medium devoid of amino acids, it was suggested that ThTP might be involved in a response to amino acid starvation [28].

In plants, ThTP is found mainly in the plastids and mitochondria of the shoots rather than the roots and peaks early during the light period and the authors suggest that it may signal ThDP sufficiency [29].

\subsection{Two Different Mechanisms of Synthesis of ThTP: Adenylate Kinase and ATP Synthase}

Different mechanisms were put forth concerning the synthesis of ThTP, among which the most straightforward is the transfer of a phosphate group from ATP to ThDP according to the reaction ThDP + ATP $\leftrightharpoons$ ThTP + ADP catalyzed by a ThDP:ATP phosphotransferase [30] (for a review, see [16]). However, such a mechanism was never confirmed.

It is important to emphasize that ThTP, like ATP and other nucleoside triphosphates, is an "energy-rich" compound with two phosphoanhydride bonds and a high phosphoryl transfer potential. Its synthesis thus requires a significant energy input.

It has now been firmly established that ThTP may be formed by two different mechanisms. The first mechanism is the synthesis of ThTP by cytosolic adenylate kinase 1 (AK1, myokinase, EC 2.7.4.3) according to the reaction first reported by [28]: ThDP + ADP $\leftrightharpoons$ ThTP + AMP instead of the more canonical reaction 2 ADP $\leftrightharpoons$ ATP + AMP. Hence, in mammalian liver and skeletal muscles, ThTP is essentially synthesized by cytosolic AK1, explaining why ThTP is mainly found in the cytosolic fraction in these tissues [26,31-33].

Bacterial AKs (for instance, E. coli AK shares several regions of high homology with AK1 [34]) are also able to synthesize ThTP according to the above reaction [35]. Hence, ThTP synthesis seems to be a rather general property of type 1 AKs. With recombinant enzymes, ThTP synthesis is over $10^{6}$ times lower than ATP synthesis [35], but this might be enough to ensure a constitutional and cytosolic synthesis of ThTP. However, ThTP synthesis by AK1 is not the only mechanism as ThTP levels are hardly decreased in tissues of transgenic AK1 knockout mice [36].

The second mechanism of ThTP synthesis seems to be related to ATP synthase (EC 7.1.2.2, $\mathrm{F}_{\mathrm{o}} \mathrm{F}_{1}$-ATPase). Indeed, energized isolated rat brain mitochondria are able to synthesize ThTP from ThDP and $P_{i}$, which can then be exported in exchange with $P_{i}$ or nucleotides [32]. This synthesis is tightly coupled to the respiratory chain and depends on the existence of a transmembrane $\mathrm{H}^{+}$gradient, suggesting that ThTP is synthesized by a mechanism similar to ATP and involving ATP synthase. Interestingly, only brain but not liver mitochondria were able to synthesize ThTP. This suggests a cell-specific regulation of ThTP by mitochondria. In E. coli, ThTP can accumulate to over $50 \%$ of total thiamine and is most probably synthesized by ATP synthase [37]. Very recently it was shown that in 
Arabidopsis shoots, ThTP synthesis oscillates during the diel period and may accumulate during the early light period [29]. This synthesis occurs in the plastids and mitochondria, is dependent on the proton gradient, and is coupled to photosynthetic processes, again suggesting the involvement of chloroplast and mitochondrial ATP synthases. ThTP synthesis has not yet been reported with purified and reconstituted ATP synthase, but the purified $\mathrm{F}_{1}$ fragment may hydrolyze ThTP at a very low rate [37].

\subsection{Regulation of Intracellular ThTP Concentrations}

Mitochondria, E. coli and chloroplasts, are able to synthesize ThTP, strongly linking this synthesis to proton gradient-dependent energy processes. It is not established whether this synthesis is a mere side reaction of ATP synthase or a physiologically relevant process. The fact that mitochondrial ThTP synthesis is tissue specific (brain mitochondria may synthesize ThTP, while liver mitochondria may not [32]) would suggest the latter. With this respect, it is also interesting to note that ThTP synthesis seems to be decreased in cardiovascular system biopsies of patients with heart failure syndrome [26]. Indeed, the ratio ([ThTP + $[$ ThMP])/([Thiamine] + [ThMP]), which we called the "thiamine phosphorylation ratio", was low $(<1)$ in these patients, while it did not correlate with age or underlying neoplastic disease. As these patients suffer from metabolic shifts and decreased energy generating processes, this observation emphasizes the coupling of ThTP synthesis to cell energy metabolism. Indeed, ThTP steady-state concentrations are a balance between synthesis and hydrolysis [24,25]. In case of energy shortage, hydrolysis would prevail, leading to accumulation of ThMP (Figure 1). Intracellular ThDP concentrations are one or two orders of magnitude higher than those of ThTP and ThMP, so that no significant changes in ThDP levels are observed when ThTP is hydrolyzed but ThMP accumulates.

An intriguing observation was that some tissues have an extremely high proportion of ThTP compared to total thiamine, sometimes exceeding $70 \%$. This is the case for pig [33] and chicken [38] skeletal muscles and fish electric organs (which are ontogenetically derived from skeletal muscle) from Torpedo marmorata [39] and Electrophorus electricus [40], all tissues with high AK1 activity. Why these tissues specifically accumulate ThTP remained a mystery until it was understood that, though AK1 is responsible for ThTP synthesis in the tissues (but also in the skeletal muscle of other species), THTPA hydrolyzes ThTP in a highly efficient manner except in fish, birds, and pigs (Table 1). Indeed, fish have a specific THTPA, but its activity is orders of magnitude lower than that of the mammalian enzymes and no significant cytosolic ThTPase activity has ever been measured in fish tissue [15,41]. Birds have completely lost a region encompassing 30 genes including the gene coding for THTPA [41]. Due to several amino acid changes, the domestic pig expresses a catalytically inactive THTPA [42]. Hence, the accumulation of ThTP in skeletal muscle and electric organs is the consequence of high AK 1 activity combined with low or absent THTPA activity. These results emphasize the importance of THTPA in the regulation of cytosolic ThTP concentrations.

Rats, genetically selected for high-alcohol sensitivity, have higher ThTP levels in liver and brain compared with low-alcohol sensitivity animals [43], but the significance of this observation remains to be established.

Based on expression analysis, a recent study suggested a correlation between the pituitary tumor-transforming gene family and ThTP metabolism [44], but obviously they confounded ThTP with thymidine triphosphate.

\subsection{The Special Case of ThTP Synthesis in E. coli}

For a long time, we have been looking for conditions that would alter intracellular ThTP concentrations in a simple system, such as cultured neuroblastoma cells; however, no reproducible conditions were found (unpublished results). We now know that in these cells, ThTP is synthesized constitutionally by AK and that THTPA is not expressed at the protein level in neuroblastoma cells in its active from, though the mRNA is present and ATP synthase does not play a significant role in ThTP synthesis in these cells [26]. 
Therefore, we looked for a simpler model, such as E. coli. Indeed, we found that in E. coli cells, ThTP is detected under very specific conditions: aerobic growth, amino acid starvation, and a suitable sugar or sugar-derived carbon-source [28,37], conditions recently confirmed by another group [29]. ThTP synthesis is inhibited by amino acids, with some (Cys, Glu, Arg, and Trp) being particularly effective, pointing to a metabolic regulation of ThTP synthesis. The requirement of a carbon source (different from amino acids) is explained by the necessity of generating a proton gradient. However, not all carbon sources that generate a proton gradient were equally efficient to significantly boost ThTP synthesis. Indeed, the most efficient were those feeding into glycolysis (D-glucose, D-fructose, D-gluconate, pyruvate, and L-lactate), while intermediates of the citric acid cycle (citrate, oxoglutarate, fumarate, malate, and oxaloacetate) were inefficient. Some (acetate, glutamate, succinate) were of intermediate efficiency.

This suggests that pyruvate oxidation is an essential condition for ThTP synthesis [37]. When pyruvate oxidation is blocked by fluoroacetate, which is transformed into fluorocitric acid, an inhibitor of aconitase [45], no ThTP synthesis occurs (Figure 2A). Pyruvate is required because it yields $\mathrm{NADH}$, a substrate for the respiratory chain. The requirement for oxygen was later recognized when it was found that ThTP is synthesized by ATP synthase, requiring an active respiratory chain [37]. However, it appears that pyruvate is also required because it yields an "activator" essential for ThTP synthesis. This activator is supposedly synthesized either during the early reactions of the Krebs cycle or after the branching point towards glutamate and glutamine (Figure 3). In order to test this hypothesis, we used an E. coli strain deleted in glutamine synthetase (Figure 2B). This strain was unable to accumulate ThDP, suggesting that glutamine, or a downstream metabolite, might activate ThTP synthesis or the accumulation of a metabolite upstream of glutamine would inhibit ThTP synthesis.
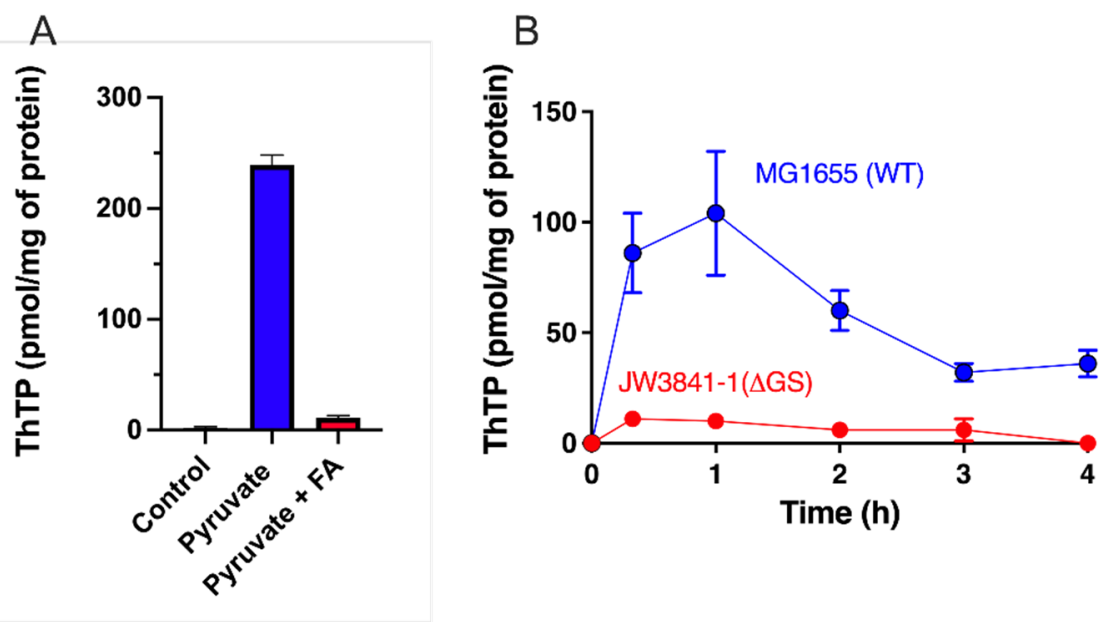

Figure 2. Importance of the pyruvate-glutamine axis for ThTP synthesis in E. coli. (A) Inhibition of ThTP synthesis by fluoroacetate (FA). E. coli cells from the BL21 strain were grown in LB medium and then transferred into a M9 minimal medium (devoid of amino acids) for $20 \mathrm{~min}\left(37^{\circ} \mathrm{C}, 250 \mathrm{rpm}\right)$ in the absence or the presence of either pyruvate $(10 \mathrm{mM})$ or pyruvate $(10 \mathrm{mM})+$ fluoroacetate $(10 \mathrm{mM})$ and ThTP was determined by HPLC [28]. (B) ThTP synthesis is strongly decreased in a strain specifically deficient in glutamine synthetase (JW3841-1 derived from parent strain MG1655/K12 - ATCC 47076). Both strains were grown in minimal medium in the presence of $10 \mathrm{mM}$ D-glucose for the indicated times and ThTP was determined as above. Single gene deleted strain JW3841-1 [46] (CGSC \# 10775) was obtained from the Genetic Resource Center (Yale University, New Haven, CT, USA) (data are from [47] and expressed as mean $\pm \mathrm{SD}$ ).

These results again underscore the importance of a metabolic regulation of ThTP synthesis in E. coli and possibly the existence of a regulatory switch located between pyruvate and oxoglutarate [37] (Figure 3). 


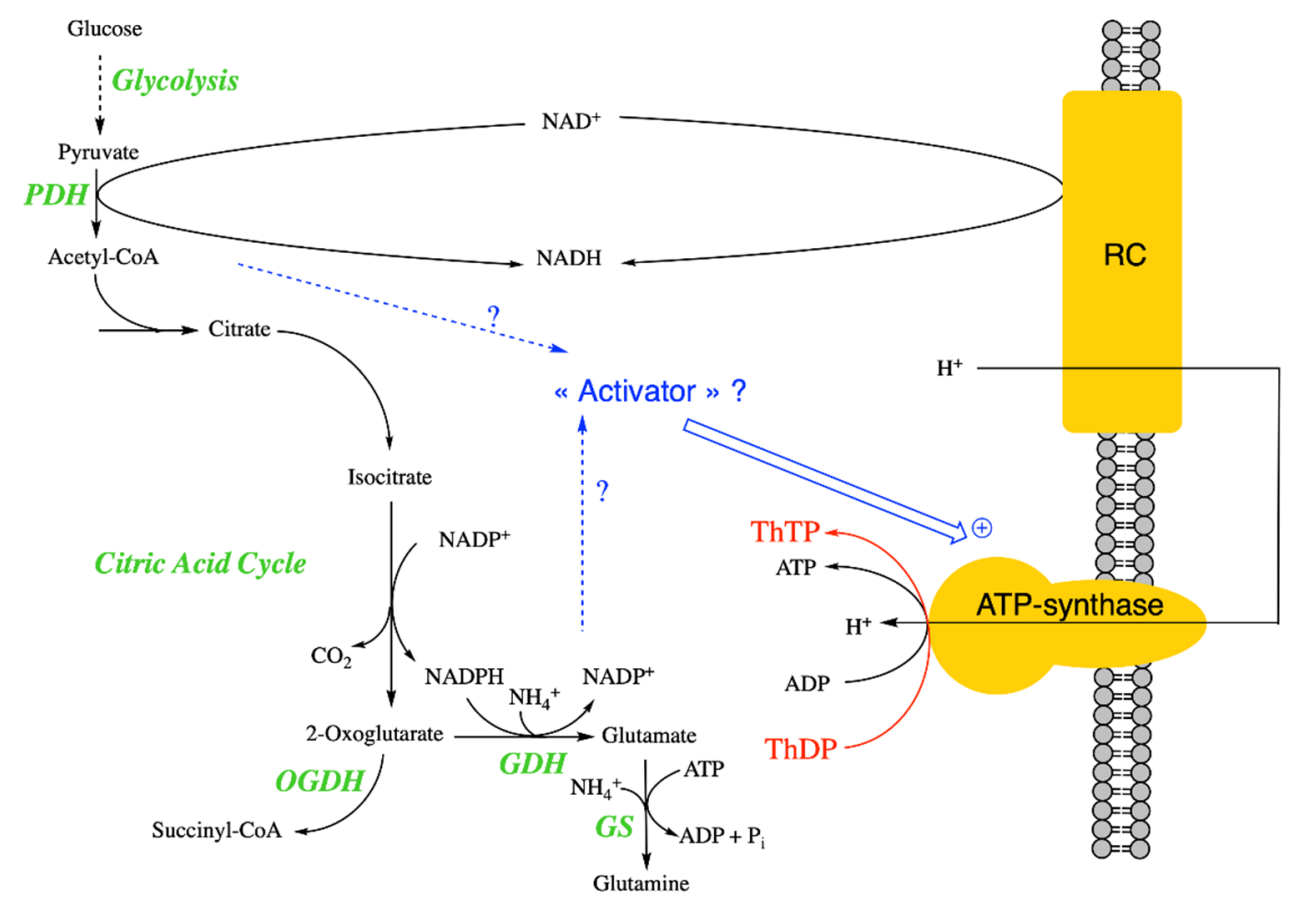

Figure 3. Mechanism of ThTP synthesis in E. coli and possible regulation. It seems that ThTP synthesis by a chemiosmotic process requires an activator synthesized either during the early reactions of the Krebs cycle or after the branching point towards glutamate and glutamine. ThTP synthesis by AK is negligible in $E$. coli under these conditions. Note that $E$. coli isocitrate dehydrogenase requires $\mathrm{NADP}^{+}$ and not $\mathrm{NAD}^{+}$as co-substrate [48] (PDH, pyruvate dehydrogenase; GDH, glutamate dehydrogenase; GS, glutamine synthetase).

\subsection{Possible Physiological Roles of ThTP in Nerve Tissue}

\subsubsection{A Specific Role of ThTP in Nerve Excitability}

Historically, it was thought that ThTP might have a specific role in membrane excitability and nerve conduction. This hypothesis was, among others, based on the following two observations:

1. The existence of very high levels of ThTP in electric organs, rich in $\mathrm{Na}^{+}$channels $[39,40]$, but this is probably just a coincidence due to high AK1 and low THTPA activity in these tissues as mentioned above.

2. The electrical stimulation of isolated nerves leads to a release of thiamine, probably resulting from a dephosphorylation shift of higher thiamine phosphoester, such as ThDP and ThTP [11].

In agreement with the latter observation, we could show that intermittent light stimulation of the photosensitive baboon Papio papio resulted in a decreased [ThTP]/[ThMP] ratio of the occipital (visual) cortex in the animals [49]. In view of what we now know about the synthesis of ThTP in nervous tissue, these results might just reflect a decreased synthesis of ThTP by ATP synthase under highly energy consuming conditions (see Section 2.3). Under such conditions, hydrolysis of ThTP would continue, leading to decreased ThTP and increased ThMP levels. ATP shortage might also lead to decreased synthesis of ThDP by thiamine di(pyro)phospkokinase (TPK1) according to the reaction thiamine + ATP ThDP + AMP (EC 2.7.6.2), the only known enzyme involved in ThDP synthesis in animals.

Hence, there is no strong evidence that ThTP may play a role in nerve excitability.

\subsubsection{ThTP and Neurotransmitter Release}

Several studies suggest an involvement of ThTP in neurotransmitter release. Hence, ThTP $(>0.1 \mathrm{mM})$, but also ThDP, induced a $\mathrm{Ca}^{2+}$-dependent dopamine release in the rat striatum [50]. This effect might be mediated by extracellular purinoceptors. An ancient 
study suggested a role of thiamine, and possibly ThTP, in cholinergic transmission in the electric organ of Torpedo marmorata [39]. This was based on the presence of very high concentrations of thiamine and its phosphate esters in the cytoplasm of the electric organ.

\subsubsection{ThTP and Protein Phosphorylation}

As pointed out above, ThTP, like ATP, has a high phosphate group transfer potential and could thus be a phosphate donor in protein phosphorylation reactions. This hypothesis was tested using $\left[\gamma^{-32} \mathrm{P}\right]-\mathrm{ThTP}$ on membranes of the acetylcholine-rich electric organ of T. marmorata. In these preparations, ThTP indeed phosphorylated the protein rapsyn, associated with the nicotinic acetylcholine receptor and essential for the clustering of the receptors at the neuromuscular junction [51]. This phosphorylation occurred at low ThTP concentrations $(5-25 \mu \mathrm{M})$ on histidine residues in the absence of added kinases. The physiological relevance of this phosphorylation, however, remains to be attested.

\subsubsection{ThTP and Membrane Chloride Permeability}

ThTP was also thought to be directly involved in the regulation of ion channels in nerve cells [52]. When synaptoneurosomal membrane vesicles prepared from rat brain were incubated with thiamine or ThDP in order to increase intravesicular ThTP levels, the ThTP levels correlated with chloride membrane permeability [53-55]. In order to identify possible chloride channels involved in these permeability changes, we tested the addition of ThTP to excised inside-out patches in cultured mouse neuroblastoma cells. Under these conditions, ThTP at relatively low concentrations $(<10 \mu \mathrm{M})$ activated very high conductance chloride channels of 300-400 pS, the so-called maxi chloride channel [56]. At this time, neither the identity nor the role of this channel was known. It now appears that its core component is the organic anion transporter SLCO2A1, which, in its resting (closed) state, functions as a prostaglandin transporter and in its active (open) state as a channel releasing mainly chloride and ATP [57]. This channel is thought to be involved in cell volume regulation and purinergic cell-to-cell signaling.

\subsubsection{ThTP and Glutamate Dehydrogenase}

ThTP $(1$ and $10 \mu \mathrm{M})$ allosterically activates commercial preparations of the purified glutamate dehydrogenase (GDH) from bovine liver [14], though no in vivo data are available. GDH is at the crossroads of carbon and nitrogen metabolism. Indeed, it is thought that in mammals, the reaction catalyzed by GDH is favored in the catabolic sense (synthesis of 2-oxoglutarate from glutamate). 2-Oxoglutarate can be either catabolically decarboxylated by 2-oxoglutarate dehydrogenase and continue through the citric cycle or anabolically funneled into amino acid metabolism by transamination. In microorganisms and possibly plants, GDH functions in the anabolic sense of glutamate synthesis from 2-oxoglutarate and $\mathrm{NH}_{4}{ }^{+}$and may play a role in nitrogen assimilation [58]. Hence, the balance of these pathways is essential for the energy status of the cells in all organisms.

\section{Thiamine Triphosphatases}

No specific ThTPases have been identified in microorganisms, fungi, or plants, but a membrane-associated and a cytosolic ThTPase have been extensively studied in animal cells. In addition to these two ThTPases, myosin is able to hydrolyze ThTP to ThDP [59]. ThTP may bind to a regulator site on myosin, but it does not seem to affect muscle contraction [60].

E. coli represents a particularly interesting case. In E. coli, ThTP accumulation is always transitional, with a maximum after 1 or $2 \mathrm{~h}$. Thereafter, ThTP levels steadily decrease (Figure 2B, [28]). Decreased ThTP levels are concomitant with increased ThDP levels, suggesting a mechanism of hydrolysis that starts to prevail over synthesis. No specific enzymatic mechanism of ThTP hydrolysis has been evidenced so far in E. coli. However, ThTP is hydrolyzed by the purified $\mathrm{F}_{1}$ subunit of E. coli ATP synthase with an apparent $K_{\mathrm{m}}$ of $40 \mu \mathrm{M}$ but a very low $\mathrm{k}_{\text {cat }}$ of $1.5 \mathrm{~min}^{-1}$ [37]. This result is not surprising if 
ATP synthase is responsible for ThTP synthesis, and one can expect that, as for ATP, ThTP is hydrolyzed by $\mathrm{F}_{1}$-hydrolyzing activity.

\subsection{Mammalian Membrane-Associated ThTPase}

A membrane-associated ThTPase is present ubiquitously in mammalian cells. It has not yet been identified at the molecular levels and it is not clear whether this enzymatic activity results from one or several enzymes and to what level it is physiologically relevant. This enzyme retained some attention as thiamine was thought to have a role in nerve excitability, a hypothesis now more or less abandoned in favor of a more metabolic role $[16,23]$.

This ThTPase activity was first reported in the rat brain [61], but it seems to exist in most mammalian tissues, where it is found in all particulate fractions. It is activated by both $\mathrm{Mg}^{2+}$ and $\mathrm{Ca}^{2+}$ and has a $\mathrm{K}_{\mathrm{m}}$ in the millimolar range for ThTP. It is competitively inhibited by low concentrations of ATP and ADP, with $\mathrm{IC}_{50}$ values of $20 \mu \mathrm{M}$ for ATP and $75 \mu \mathrm{M}$ for ADP [62]. These results suggest that the active site has a much higher affinity for adenine nucleotides than for thiamine compounds. It remains possible that the enzyme would be a nucleoside triphosphatase with broad substrate specificity.

A membrane-associated ThTPase with somewhat different properties was later described in electric organs $[40,63,64]$ and skeletal muscle [65]. It is not clear whether it is distinct from the brain enzyme or just an isoform with different properties. The distinctive feature of this ThTPase is its strong activation by chaotropic anions $\left(\mathrm{I}^{-}>\mathrm{SCN}^{-}>\mathrm{NO}_{3}{ }^{-}\right.$ $\left.>\mathrm{Br}^{-}>\mathrm{Cl}^{-}\right)$, a property not observed for the brain enzyme, which, on the contrary, is inhibited by anions. Though the enzyme could be solubilized by detergents, the activity was lost during purification [66].

Very recently, the solubilization and the partial purification of the chicken liver enzyme was reported [67]. The ThTPase activity was coeluted with ATP and ITP hydrolyzing activities in a high molecular mass fraction and the $\mathrm{K}_{\mathrm{m}}$ for ThTP was about $2 \mathrm{mM}$.

From what we presently know, it is likely that the membrane-associated ThTPase activities are not from genuine ThTPases but rather nucleoside triphosphatases with broad substrate specificity.

A membrane-associated brain synaptosomal protein, binding thiamine phosphorylated derivates, including ThTP, seems to have ThTPase activity $[68,69]$. The authors report a pH optimum of 7.4 and an apparent $\mathrm{K}_{\mathrm{m}}$ of $52 \mu \mathrm{M}$, which is somewhat lower than reported earlier for the membrane-associated ThTPase. It is not clear whether this protein is identical to the membrane-associated brain ThTPase mentioned above.

\subsection{Soluble 25-kDa ThTPase (THTPA)}

\subsubsection{Characterization, Structure, and Evolution of THTPA}

A soluble ThTPase (THTPA) was first described in 1972 [70]. This enzyme proved to be more interesting than the membrane-associated enzyme. Though mainly cytosolic, one study suggested that a soluble ThTPase with somewhat different properties exists in the mitochondrial matrix and intermembrane space [71]. It is not clear whether it is the same or a different enzyme.

THTPA was purified to homogeneity by A. Makarchikov in 1992 from bovine brain [72]. This enzyme requires $\mathrm{Mg}^{2+}$ as cofactor, but it is inhibited by $\mathrm{Ca}^{2+}$, but its most interesting property is its near absolute specificity for ThTP as substrate and a relatively low $\mathrm{K}_{\mathrm{m}}$ $(43 \mu \mathrm{M})$, suggesting that it is a genuine ThTPase. The recombinant human ThTPase was cloned, produced in E. coli, purified, and sequenced in 2002 [73]. The human enzyme is composed of 230 amino acids, has a predicted molecular mass of $25.55 \mathrm{kDa}$, and is localized to chromosome 14q11.2. ThTPase activity and THTPA mRNA are widely distributed in mammalian tissues, with no apparent specificity for nervous tissue [73,74]. Shortly after the publication of the primary structure of THTPA, Iyer and Aravind detected the presence of a common motive between mammalian THTPA and the CyaB protein from Aeromonas hydrophila, a non-canonical adenylate cyclase [75]. More importantly, they showed that "the 
CyaB like adenylyl cyclase and the mammalian ThTPases define a novel superfamily of catalytic domains called the $\mathrm{CYTH}$ (contraction of $\mathrm{CyaB}$ and THTPA) domain that is present in all three superkingdoms of life". The conserved CYTH motive is mainly formed by the sequence EXEXK (where $X$ is any amino acid) characteristic of this family and is an ancient enzymatic domain, present in the Last Universal Common Ancestor (LUCA) and involved in nucleotide or organic phosphate metabolism [75]. In 2006, Gong et al. noticed similarities between the crystal structure of Cet1 RNA triphosphatase (EC 3.1.3.33) from Saccharomyces cerevisiae and the structures of bacterial and archaeal CYTH proteins [76]. All these enzymes had an active site composed of an eight-strand B-barrel forming a topologically closed tunnel. They proposed that this tunnel fold was the prototype of a larger superfamily termed triphosphate tunnel metalloenzymes (TTMs), including the CYTH branch and able to bind triphosphorylated substrates, such as ATP and ThTP, and requiring divalent metal ions as activators. Some bacterial members of this family, such as the N. europaea (NeuTTM) and E. coli (YgiF), are functional inorganic tripolyphosphatases $[77,78]$ and so are the $A$. thaliana ortholog AtTTM3 [79] and the Hippeastrum HpAC1 protein [80] (Figure 4). The latter was considered an adenylate cyclase until its enzymatic and structural characterization revealed predominant triphosphatase activity. Hence, the authors suggested renaming the protein HpPP1 or HpTTM1 [80]. In A. thaliana, two other TTMs, TTM1 and TTM2, are involved respectively in pathogen resistance and leaf senescence [81]. Surprisingly, both have a higher activity towards PPi than towards triphosphorylated substrates and both carry a uridine kinase domain in addition to the CYTH domain. The only archaeal TTM protein characterized enzymatically proved to be a tripolyphosphatase [82].

The picture that emerges is that TTM proteins evolved from an inorganic tripolyphosphatase acquiring new substrate specificities in fungi and some protists (RNA triphosphatase) and animals (ThTPase) or even new catalytic mechanisms in some bacteria (CyaB like adenylyl cyclase) [83]. The recombinant form of the plant Brachypodium distachyon (BdTTM3) even shares high triphosphatase activity (binding both tripolyphosphate and ATP) and low adenylate cyclase activity and might be involved in the mechanism underlying responses to wounding stress [84].

Interestingly, all metazoans (from sea anemone to humans) possess one TTM protein with ThTPase activity. Birds are a notable exception: a whole region of 30 genes, including the thtpa gene, has disappeared on chromosome 14 [41], leaving this branch as the only one known without a TTM protein. Moreover, fish and pigs, though retaining their THTPA orthologs, have practically no activity $[15,41,42]$, which is probably the reason why ThTP accumulates in these tissues (see Section 2.3 and Table 1).

The mammalian enzyme is well conserved, with an estimated evolutionary period of 4.4 million years, corresponding to an average rate of amino acid substitutions of $1.41 \times 10^{-9}$ per site per year [85]. The three-dimensional structure of mammalian THTPA was obtained by NMR [86] and crystallography [41], confirming an open tunnel structure of the active site, closed by substrate binding (Figure 5). Mass spectrometry and site-directed mutagenesis confirmed a high affinity (micromolar range) and high specificity for ThTP, probably due to the Trp-53 residue responsible for a stacking interaction with the thiazole ring of ThTP [41]. On the other hand, Tyr-39 and Lys-65 are important residues for catalysis forming a catalytic dyad [41]. 


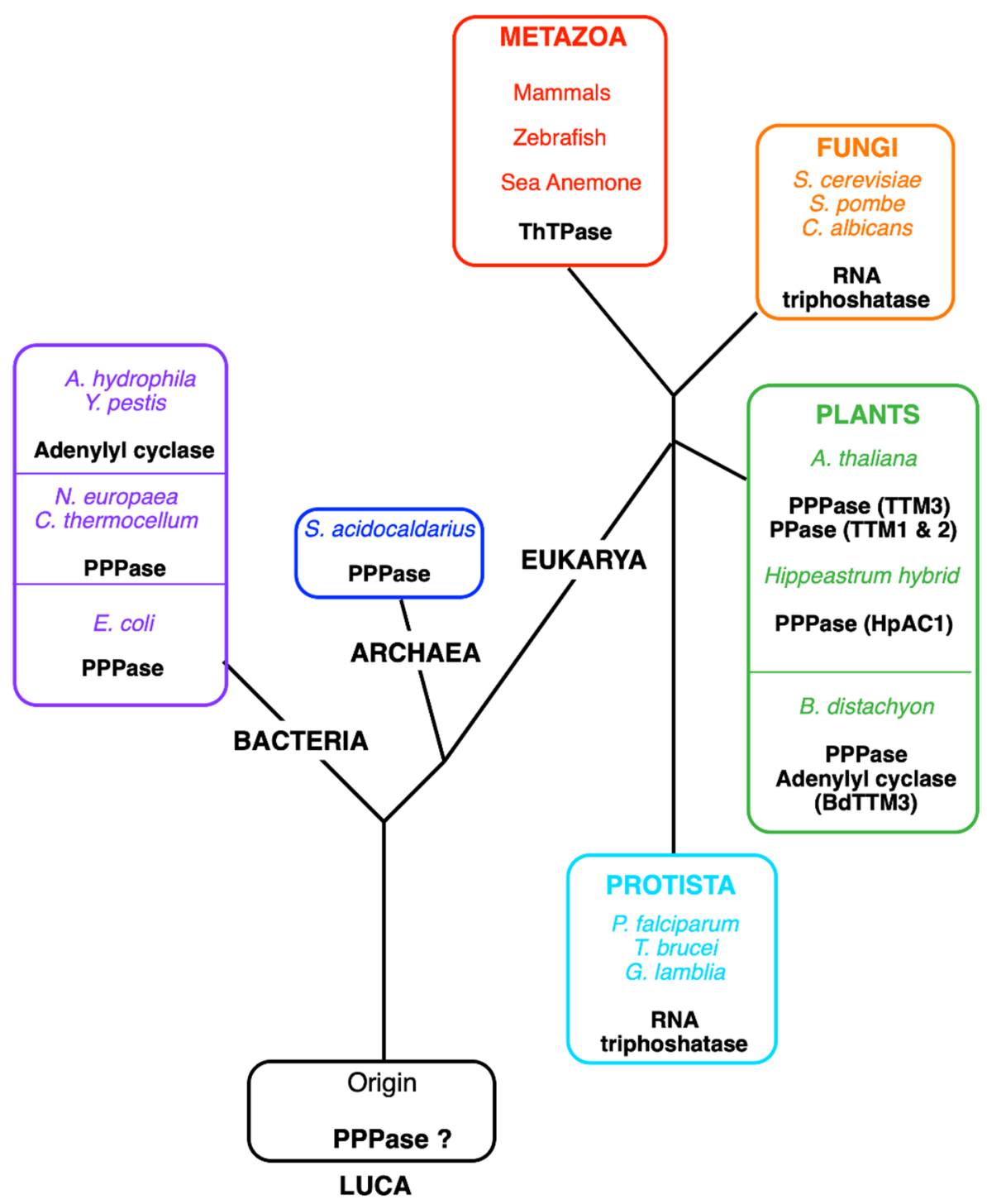

Figure 4. Tentative phylogenetic tree of the TTM (CYTH) superfamily. Currently, five different enzyme activities have been identified for members of the CYTH superfamily: tripolyphosphatase in bacteria (C. thermocellum, N. europaea, E. coli), an Archaea (Sulfolobus acidocaldarius) and plants (A. thaliana and Hippeastrum hybrids), adenylyl cyclase (in A. hydrophila and Y. pestis), RNA triphosphatase (in fungi and some protozoans), and ThTPase (in most metazoans, including vertebrates except for birds). Lately, pyrophosphatase activity (PPase) was recognized in A. thaliana TTM1 and TTM2, proteins containing a TTM and a uridine kinase domain [87]. The plant B. distachyon (BdTTM3) shares high triphosphatase activity and low adenylyl cyclase activity [84]. We hypothesize that the original activity in the Last Universal Common Ancestor (LUCA) was the hydrolysis of low molecular mass polyphosphates.

Though, $\mathrm{Mg}^{2+}$ is required for catalytic activity, and $\mathrm{Mg}^{2+}$ tightly binds to ThTP, it seems that $\mathrm{Mg}^{2+}$ dissociates from ThTP and binds to a different site, probably including the two glutamate residues of the EXEXK CYTH motive [41]. 


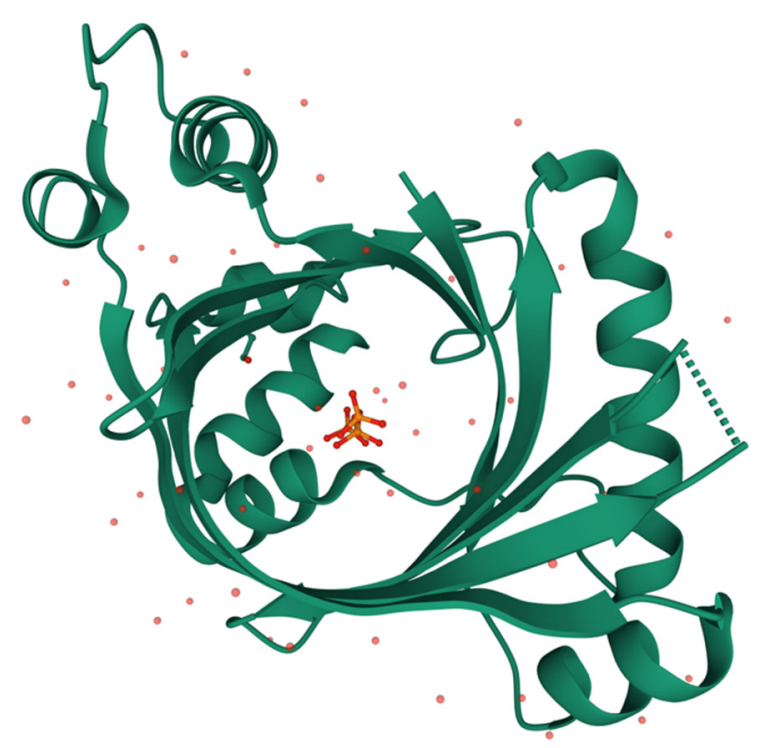

Figure 5. Three-dimensional structure of human THTPA in complex with inorganic tripolyphosphate (RCSB PDB ID 3TVL, https:/ / www.rcsb.org) [41]. Image created using $\mathrm{Mol}^{*}$ [88].

\subsubsection{Possible Physiological Roles of THTPA and Regulation}

From the data mentioned above, the very high cytosolic concentrations of ThTP in animal tissues where THTPA is either absent (chicken skeletal muscle) or poorly active (pig skeletal muscle, E. electricus electric organ) suggest that THTPA is indeed involved in the regulation of cytosolic ThTP concentrations. This is further emphasized by its high specificity for ThTP as substrate. However, the physiological significance of this reaction remains obscure.

THTPA is mainly expressed in adult tissues. In the rodent brain, using in situ hybridization and immunohistochemistry, the strongest staining was observed with both methods in hippocampal pyramidal neurons, as well as cerebellar granule cells and Purkinje cells [89]. Soluble ThTPase activity is low in cultured and embryonic cells [26], but as mRNA is abundant, we proposed that the expression of the protein may be controlled post-transcriptionally or by post-translational modification, possibly through the highly conserved 200-nucleotide 3'-untranslated mRNA region [74]. With this respect, it should be emphasized that thtpa expression may be controlled by genes (Ndrg-1, melanotransferrin) involved in cancer cell models [90,91].

A recent study suggested that THTPA, among several other proteins, might serve as biomarkers for stratification of tumor subtypes in breast cancer [92].

We produced transgenic mice overexpressing bovine ThTPase in mice with the aim of making the animals devoid of ThTP. These mice indeed had about two-fold increased ThTPase activities, but ThTP levels were unchanged [16]. Indeed, mouse ThTPA is catalytically highly efficient and ThTP levels are already very low. Moreover, we did not know at the time that, except for skeletal muscle, most of the ThTP is produced intramitochondrially by ATP synthase. These mice did not display any evident phenotypic specificities.

Another possibility would be that cytosolic ThTP accumulation would be cytotoxic. This is, however, clearly not the case in pig and chicken skeletal muscle and electric organs.

Linster et al. suggested the interesting hypothesis that THTPA is involved in metabolite repair, i.e., the regeneration of the coenzyme ThDP from ThTP, formed as a byproduct of other reactions, such as adenylate kinase or ATP synthase [93]. However, even when THTPA activity is absent, ThTP, except for pig and chicken skeletal muscle and electric organs, remains low compared to ThDP $[15,26,33,40]$. 
Table 1. Relative ThTP content and AK1 and THTPA activities in various animal species. This table shows a correlation between, on the one hand, ThTP levels and, on the other hand, low ThTPA activity and high AK1 activity.

\begin{tabular}{|c|c|c|c|}
\hline Species & $\begin{array}{c}\text { AK1 } \\
\left(\mu \mathrm{mol} \mathrm{min}^{-1}\right. \\
\mathrm{mg}^{-1} \text { Protein) }\end{array}$ & $\begin{array}{c}\text { THTPA } \\
\left(\mathrm{nmol} \mathrm{min}^{-1}\right. \\
\left.\mathrm{g}^{-1} \mathrm{ww}\right)\end{array}$ & $\begin{array}{c}\text { ThTP } \\
\left(\text { nmol g } \text { g }^{-1} \text { ww) }\right.\end{array}$ \\
\hline Fish & & & \\
\hline E. electricus electric organ & - & n. d. ${ }^{1}$ & $3.9 \pm 0.5(87 \%)^{1}$ \\
\hline E. electricus brain & - & n. d. 1 & $0.37 \pm 0.05(7.1 \%)^{1}$ \\
\hline T. marmorata electric organ & - & n. d. 1 & $45 \pm 4(38 \%)^{2}$ \\
\hline \multicolumn{4}{|l|}{ Birds } \\
\hline Chicken skeletal muscle & $1.6 \pm 0.1^{3}$ & n. d. & $3.7(71)^{4}$ \\
\hline Chicken brain & - & n. d. & $0.92(8.4 \%)^{4}$ \\
\hline \multicolumn{4}{|l|}{ Mammals } \\
\hline Pig skeletal muscle & $1.03+0.15^{3}$ & $12.5 \pm 0.5^{4,6}$ & $20(64 \%)^{4}$ \\
\hline Mouse skeletal muscle (wt) & $1.3 \pm 0.2^{3}$ & $42^{3}$ & $0.026 \pm 0.006(0.35 \%)^{3}$ \\
\hline Mouse skeletal muscle $\left(\mathrm{AK}^{-/-}\right)$ & - & - & $0.026 \pm 0.008(0.36 \%)^{3}$ \\
\hline Mouse brain (wt) & $0.16 \pm 0.2^{3}$ & $280 \pm 30^{5}$ & $0.009 \pm 0.003(0.09 \%)^{3}$ \\
\hline Mouse brain $\left(\mathrm{AK}^{-\prime-}\right)$ & $0.02 \pm 0.01^{3}$ & - & $0.014 \pm 0.01(0.14 \%)^{3}$ \\
\hline
\end{tabular}

${ }^{1}[40] ;{ }^{2}[39] ;{ }^{3}$ [36]; ${ }^{4}[15] ;{ }^{5}$ [74]; ${ }^{6}$ This activity is probably the result of other ThTPases than THTPA. (-, not measured; $n$. d.; not detected; ww, wet weight).

We tried to produce thtpa knockout mice [94]. KO mice were generated from embryonic stem cell clones obtained from the Knockout Mouse Project (KOMP) repository at UC Davis (www.komp.org). We could generate chimera derived from the stem cells and all were partly $\mathrm{THTPA}^{+/+}$and partly $\mathrm{THTPA}^{+/-}$. However, none of the chimerae transmitted the mutation: 12 chimerae were generated and a total of 455 pups were obtained. We genotyped all of them and, surprisingly, they were all wild type. This could mean either that thtpa is essential for the differentiation of functional spermatozoids or the introduction of the KOMP cassette led to the disruption of genes essential for spermatozoid differentiation. A role of thtpa in sperm cells is supported by a very high expression of its mRNA in testis with the highest expression observed in poorly differentiated spermatogonia close to the basal lamina, while no signal was observed in spermatozoids [74].

\section{Adenylated Thiamine Nucleotides}

\subsection{Discovery, Chemical Synthesis, and Chemical Properties}

When working on the synthesis of ThTP in E. coli cells, we observed a new chromatographic peak appearing under conditions of carbon starvation [28], hence essentially conditions opposite to those inducing the appearance of ThTP. Here, it must be emphasized that analysis of thiamine compounds relies on the precolumn derivatization to fluorescent thiochrome derivatives [95]. This new fluorescent peak was not observed in the absence of thiamine-specific precolumn derivatization and had fluorescence excitation and emission spectra compatible with a thiochrome derivative [96], suggesting that it might correspond to a new thiamine derivative. After purification and identification using a combination of mass spectrometry and NMR, it proved to be an adenylated thiamine derivative, which could be either considered as thiaminylated ATP or adenylated ThDP (Figure 1). While many adenylated $\mathrm{B}$ vitamins are known (i.e., $\mathrm{NAD}^{+}, \mathrm{FAD}$, acetyl-CoA) and are considered to be remnants from an RNA world [97], this was the first adenylated thiamine compound ever to be identified. As this molecule exists in only very small concentrations (micromolar and submicromolar concentration range) as is the case for most vitamins as well as its opposite regulation in E. coli compared with ThTP, we preferred the term adenosine thiamine triphosphate (AThTP) rather than thiaminylated ATP, so as to emphasize its role as a vitamin derivative. AThTP was shown to be present not only in E. coli (where it may account for up to $15 \%$ of total thiamine), but also in much smaller concentrations in animals, fungi, and the roots of $A$. thaliana plants $[17,96,98]$. The latter observation could however not be reproduced in another study [29]. 
Despite a relatively broad distribution, nothing is known about the regulation of the synthesis or hydrolysis of ThTP in eukaryotic cells and it cannot be excluded that AThTP is a waste product.

AThTP could be chemically synthesized by condensation of ADP and ThDP catalyzed by $\mathrm{N}, \mathrm{N}^{\prime}$-dicyclohexylcarbodiimide $[17,96]$ and identified by a combination of ESI tandem MS and ${ }^{1} \mathrm{H}-{ }^{13} \mathrm{C}-{ }^{31} \mathrm{P}-\mathrm{NMR}$. More recently, improved methods of synthesis have been proposed $[99,100]$.

During this synthesis, we observed the formation of another compound, which proved to be adenosine thiamine diphosphate (AThDP). This compound, could be detected in small amounts in E. coli and mammalian liver, suggesting that it is a naturally occurring molecule [96].

Based on ${ }^{1} \mathrm{H}-\mathrm{NMR}$ and molecular modeling, we proposed that both AThTP and AThDP exist under a U-shaped folding, bringing together the adenine and thiamine moieties [96]. In such structures, the C-2 proton of the thiazolium ring of thiamine, which is required for the catalytic activity of ThDP, is embedded in a hydrophobic environment formed by the adenine and aminopyrimidine rings, making it improbable that AThTP and AThDP are catalytically active.

\subsection{Regulation of AThTP Synthesis in E. coli}

As mentioned above, AThTP is synthesized in E. coli under conditions of carbon starvation, but a closer analysis revealed a much more complex situation [35].

1. It is not the absence of a carbon source per se that triggers AThTP synthesis, but the absence of its metabolization. Hence, AThTP accumulates in the presence of glucose when glycolysis is inhibited by iodoacetate, or in the presence of lactate when the respiratory chain is inhibited by $\mathrm{KCN}$.

2. AThTP synthesis probably requires a low molecular weight factor seemingly synthesized from pyruvate. Indeed, uncouplers, such as CCCP, induce ThTP synthesis only in the presence of pyruvate or a pyruvate-yielding substrate (D-glucose or L-lactate).

3. ThTP is an inhibitor of AThTP synthesis, explaining at least in part that both compounds never accumulate together.

Hence, AThTP may accumulate under two different conditions of severe energy stress: absence of an energy substrate (or inhibition of its metabolization) and uncoupled pyruvate oxidation. However, there is no obvious link with the stringent response to carbon starvation or catabolite repression [35].

\subsection{AThTP Is Synthesized by a High Molecular Weight Complex in E. coli}

An AThTP synthesizing activity, according to the reaction ThDP $+\mathrm{ATP}(\mathrm{ADP}) \rightleftharpoons$ AThTP $+\mathrm{PP}_{\mathrm{i}}\left(\mathrm{P}_{\mathrm{i}}\right)$, was isolated from an E. coli supernatant after precipitation and Sephadex G-200 chromatography [101]. The enzyme activity was eluted in two nearly equal peaks of 355 and $190 \mathrm{kDa}$, the first probably a dimer of the second. This finding was confirmed more recently and both peaks contained multiple protein bands when analyzed by SDSPAGE [102].

The synthesis required ThDP and either ATP or ADP as substrates. A divalent cation, either $\mathrm{Mn}^{2+}$ or, the more physiological, $\mathrm{Mg}^{2+}$ was also required. The kinetics were complex, with a lag period and a sigmoidal behavior with respect to ADP (Hill coefficient $=2.1$ ), in agreement with a multisubunit complex. Further purification systematically led to the loss of activity, possibly because of the dissociation of the complex. We tentatively called this enzyme complex a ThDP adenylyl transferase [101].

Another important point is that the enzyme is activated by a low molecular weight organic compound present in bacterial extracts [101]. This would be in agreement with the requirement of a metabolite of pyruvate oxidation in vivo (see Section 4.2). 


\subsection{AThTP Hydrolysis in E. coli}

In contrast to ThTP accumulation, which is transient, AThTP accumulation is not: its levels remain high as long as the stress condition is present. However, addition of a carbon source to $E$. coli cells under carbon starvation will lead to the immediate disappearance of AThTP (Figure 6). The rapidity with which this disappearance occurs suggests the activation of an enzymatic mechanism of hydrolysis. An enzyme present in the bacterial membrane extracts is able to hydrolyze AThTP to ThDP and AMP [17].

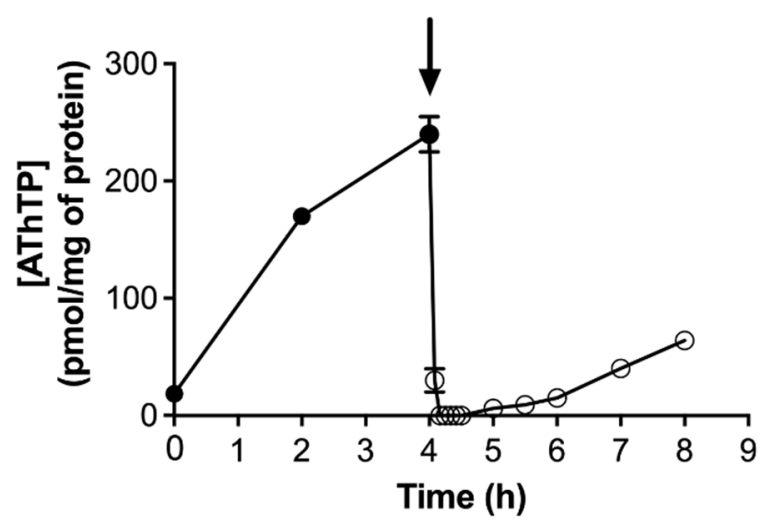

Figure 6. AThTP levels as a function of time in E. coli BL21 cells transferred to a minimal medium and incubated at $37^{\circ} \mathrm{C}$ at $250 \mathrm{rpm}$ in the absence of a carbon source. Aliquots were taken for determination of thiamine derivatives. The arrow indicates the addition of $10 \mathrm{mM}$ D-glucose (mean $\pm \mathrm{SD}, n=3$ ) (adapted from [103]).

\subsection{AThTP Hydrolysis in Animal Tissues}

In animal tissues, AThTP is hydrolyzed by a membrane-bound enzyme probably of microsomal origin [98]. In chicken and rat liver homogenates, this enzyme has a $\mathrm{pH}$ optimum of 8.0-8.5, does not require $\mathrm{Mg}^{2+}$ as cofactor, and obeys Michaelis-Menten behavior with an apparent $K_{m}$ around $50 \mu \mathrm{M}$. The enzyme activity is highest in liver and kidney tissues.

\subsection{Physiological Roles of Adenylated Thiamine Derivatives}

Concerning the dephosphorylated compound AThDP, we only know that it is present in minimal amounts in E. coli and mammalian liver and its possible role and metabolism are unknown. The fact that in mammalian tissues it is only detected in the liver, a metabolically highly active organ involved in many detoxification reactions, might suggest that AThDP is a mere byproduct, possibly of the enzyme complex responsible for AThTP synthesis.

The situation is different for AThTP. This compound accumulates in E. coli under very specific conditions of energy stress and may reach up to $15 \%$ of total thiamine. It is thus possible that it may act as some kind of alarmone.

Recently, a very interesting hypothesis was suggested: AThTP might form $5^{\prime}$-thiaminecapped RNAs [90]. The authors were able to obtain short $5^{\prime}$-thiamine-capped RNAs with T7 RNA polymerase, but the existence of such caps in bacteria now needs to be proven.

It was reported that AThTP $(10 \mu \mathrm{M})$ inhibits mammalian poly(ADP-ribose) polymerase1 , an enzyme involved in various stress-related diseases, such as diabetes mellitus [104]. Molecular modeling of the binding of AThTP to poly(ADP-ribose) polymerase- 1 suggests a U-shaped conformation of the thiamine vitamer as suggested by ${ }^{1} \mathrm{H}-\mathrm{NMR}$ studies [96]. It is, however, not known whether such an interaction occurs in vivo. However, inhibition of poly(ADP-ribose) polymerase-1 by AThTP was not reproduced in a later study [99].

Just like ThTP, AThTP activated purified GDH at $\mu$ molar concentrations [14]. 


\section{Conclusions}

Sixty years after the discovery of ThTP, its physiological remains frustratingly elusive. A specific role of ThTP in nerve excitability, as first claimed, could not be proven until now $[16,23]$. However, three major breakthroughs opened new gateways towards the understanding of its role.

1. The first was the discovery that in E. coli, ThTP is induced under conditions of amino acid starvation in the presence of a carbon source, leading to the oxidation of pyruvate [28]. These results obtained from E. coli cells cannot necessarily be extrapolated to animal cells. Indeed, there are no known conditions where animals reversibly accumulate ThTP (we do not consider here constitutive synthesis by adenylate kinase in skeletal muscle and electric organs due to inactive THTPA).

2. The recognition that, in addition to being a byproduct of AK1, a reaction that is probably physiologically irrelevant, ThTP is synthesized by ATP synthase in E. coli, in mammalian mitochondria isolated from brain, and probably plants $[29,32,37]$.

3. The molecular characterization of the soluble 25-kDa ThTPase and its extremely high specificity for ThTP as substrate $[41,73]$.

These data do not favor a role of ThTP in membrane excitability but rather a metabolic role. With this respect, it is intriguing that ThTP (and AThTP) activated purified glutamate dehydrogenase, a mitochondrial enzyme, at physiologically relevant concentrations of 1-10 $\mu \mathrm{M}$ [14]. Hence, the present data suggest that ThTP might play a role at the interface between pyruvate oxidation and amino acid metabolism (Figure 3). This is also in agreement with the observation that in E. coli, glutamine synthetase seems to be required for ThTP synthesis in vivo (Figure 2B).

As for the other protagonist, THTPA, it is difficult to assume that an enzyme with such a high specificity for its substrate ThTP and such a high catalytic efficiency would have a role unrelated to ThTP hydrolysis. The possibility that THTPA is involved in the rescue of the coenzyme ThTP [93] remains a possibility, but it is not very likely as, in the brain for instance, ThTP is synthesized inside mitochondria. An intriguing point is the apparent posttranscriptional regulation of THTPA expression and increased expression of the protein in highly differentiated versus less differentiated cells $[26,74,90]$ with the possible exception of spermatozoa [74]. It is probable that the production of a thtpa knockout mouse, provided transmitting chimera can be obtained, will yield precious information concerning the possible physiological role of the ThTP/THTPA couple.

Even more intriguing is the recent discovery of a second triphosphorylated thiamine compound, AThTP. In E. coli, AThTP is synthesized under conditions opposite to those leading to ThTP synthesis $[17,103]$, i.e., carbon starvation, membrane potential collapse, suggesting a possible role in response to energy stress.

In conclusion, it is hard to imagine that these high-energy compounds are just an accident of nature, in particular in E. coli, where they are synthesized under very specific and highly reproducible conditions of metabolic stress. Though such conditions have not yet been found in mammalian cells, they express a highly specific ThTPase involved in the regulation of cytosolic ThTP concentrations. Hence, thiamine triphosphorylated derivatives still provide a challenging topic for future studies. In particular, the study of the regulation of ThTP and AThTP in E. coli might give interesting clues as to the possible roles of these compounds. In animals, the successful production of thtpa knockout mice might be of interest. The identification of the AThTP synthesizing and hydrolyzing enzymes combined with transgenic animals might also constitute a promising approach.

Funding: L.B. is Research Director at the Fonds de la Recherche Scientifique-FNRS (Belgium).

Institutional Review Board Statement: Not applicable.

Informed Consent Statement: Not applicable.

Data Availability Statement: Not applicable. 
Conflicts of Interest: The author declares no conflict of interest.

$\begin{array}{ll}\text { Abbreviations } \\ \text { AK1 } & \text { Adenylate kinase 1 (myokinase) } \\ \text { AThDP } & \text { Adenosine thiamine diphosphate } \\ \text { AThTP } & \text { Adenosine thiamine triphosphate } \\ \text { GDH } & \text { Glutamate dehydrogenase } \\ \text { GS } & \text { Glutamine synthetase } \\ \text { ThDP } & \text { Thiamine diphosphate } \\ \text { ThMP } & \text { Thiamine monophosphate } \\ \text { ThTP } & \text { Thiamine triphosphate } \\ \text { THTPA } & \text { 25-kDa ThTPase } \\ \text { ThTPase } & \text { Thiamine triphosphatase } \\ \text { TPK1 } & \text { Thiamine diphosphokinase 1 } \\ \text { TTM } & \text { Triphosphate Tunnel Metalloenzyme }\end{array}$

\section{References}

1. Kluger, R.; Tittmann, K. Thiamin Diphosphate Catalysis: Enzymic and Nonenzymic Covalent Intermediates. Chem. Rev. 2008, 108, 1797-1833. [CrossRef]

2. Vogel, C.; Pleiss, J. The Modular Structure of ThDP-Dependent Enzymes. Proteins 2014, 82, 2523-2537. [CrossRef]

3. Bunik, V.I.; Tylicki, A.; Lukashev, N.V. Thiamin Diphosphate-Dependent Enzymes: From Enzymology to Metabolic Regulation, Drug Design and Disease Models. FEBS J. 2013, 280, 6412-6442. [CrossRef]

4. Bettendorff, L. 10. Thiamine. In Basic Nutrition and Metabolism; Present Knowledge in Nutrition 11th Edition; Marriott, B., Birt, D., Stalling, V., Yates, A., Eds.; Academic Press: Cambridge, MA, USA, 2020; Volume 1, p. 676. ISBN 978-0-323-66162-1.

5. Abdou, E.; Hazell, A.S. Thiamine Deficiency: An Update of Pathophysiologic Mechanisms and Future Therapeutic Considerations. Neurochem. Res. 2015, 40, 353-361. [CrossRef]

6. Whitfield, K.C.; Smith, G.; Chamnan, C.; Karakochuk, C.D.; Sophonneary, P.; Kuong, K.; Dijkhuizen, M.A.; Hong, R.; Berger, J.; Green, T.J.; et al. High Prevalence of Thiamine (Vitamin B1) Deficiency in Early Childhood among a Nationally Representative Sample of Cambodian Women of Childbearing Age and Their Children. PLoS Negl. Trop. Dis. 2017, 11, e0005814. [CrossRef] [PubMed]

7. Johnson, C.R.; Fischer, P.R.; Thacher, T.D.; Topazian, M.D.; Bourassa, M.W.; Combs, G.F. Thiamin Deficiency in Low- and Middle-Income Countries: Disorders, Prevalences, Previous Interventions and Current Recommendations. Nutr. Health 2019, 25, 127-151. [CrossRef]

8. Smith, T.J.; Johnson, C.R.; Koshy, R.; Hess, S.Y.; Qureshi, U.A.; Mynak, M.L.; Fischer, P.R. Thiamine Deficiency Disorders: A Clinical Perspective. Ann. N. Y. Acad. Sci. 2020. [CrossRef]

9. Todd, K.; Butterworth, R.F. Mechanisms of Selective Neuronal Cell Death Due to Thiamine Deficiency. Ann. N. Y. Acad. Sci. 1999, 893, 404-411. [CrossRef]

10. Gibson, G.; Nielsen, P.; Mykytyn, V.; Carlson, K.; Blass, J. Regionally Selective Alterations in Enzymatic Activities and Metabolic Fluxes during Thiamin Deficiency. Neurochem. Res. 1989, 14, 17-24. [CrossRef]

11. Gurtner, H.P. Aneurin Und Nervenerregung. Versuche Mit 35S Markiertem Aneurin and Aneurinantimetaboliten. Helv. Physiol. Acta 1961, (Suppl. XI), 1-47.

12. Bettendorff, L. Thiamine in Excitable Tissues: Reflections on a Non-Cofactor Role. Metab. Brain Dis. 1994, 9, 183-209. [CrossRef] [PubMed]

13. Aleshin, V.A.; Mkrtchyan, G.V.; Bunik, V.I. Mechanisms of Non-Coenzyme Action of Thiamine: Protein Targets and Medical Significance. Biochem. Biokhimiia 2019, 84, 829-850. [CrossRef] [PubMed]

14. Mkrtchyan, G.; Aleshin, V.; Parkhomenko, Y.; Kaehne, T.; Luigi Di Salvo, M.; Parroni, A.; Contestabile, R.; Vovk, A.; Bettendorff, L.; Bunik, V. Molecular Mechanisms of the Non-Coenzyme Action of Thiamin in Brain: Biochemical, Structural and Pathway Analysis. Sci. Rep. 2015, 5, 12583. [CrossRef]

15. Makarchikov, A.F.; Lakaye, B.; Gulyai, I.E.; Czerniecki, J.; Coumans, B.; Wins, P.; Grisar, T.; Bettendorff, L. Thiamine Triphosphate and Thiamine Triphosphatase Activities: From Bacteria to Mammals. Cell Mol. Life Sci. 2003, 60, 1477-1488. [CrossRef]

16. Bettendorff, L.; Lakaye, B.; Kohn, G.; Wins, P. Thiamine Triphosphate: A Ubiquitous Molecule in Search of a Physiological Role. Metab. Brain Dis. 2014, 29, 1069-1082. [CrossRef] [PubMed]

17. Bettendorff, L.; Wirtzfeld, B.; Makarchikov, A.F.; Mazzucchelli, G.; Frédérich, M.; Gigliobianco, T.; Gangolf, M.; De Pauw, E.; Angenot, L.; Wins, P. Discovery of a Natural Thiamine Adenine Nucleotide. Nat. Chem. Biol. 2007, 3, 211-212. [CrossRef]

18. Bettendorff, L.; Wins, P. Thiamin Diphosphate in Biological Chemistry: New Aspects of Thiamin Metabolism, Especially Triphosphate Derivatives Acting Other than as Cofactors. FEBS J. 2009, 276, 2917-2925. [CrossRef]

19. Rossi-Fanelli, A.; Siliprandi, N.; Fasella, P. On the Presence of the Triphosphothiamine (TPT) in the Liver. Science 1952, 116, 711-713. [CrossRef] 
20. Kiessling, K.-H. Thiamine Triphosphate in Bakers' Yeast. Nature 1953, 172, 1187-1188. [CrossRef] [PubMed]

21. Greiling, H.; Kiesow, L. Zur Biochemie Des Thiamintriphosphorsäure IV. Mitt.: Das Vorkommen von Thiamintriphosphate Im Tierischen Organismus. Z. Naturforsch. 1958, 13, 251-252. [CrossRef]

22. Rossi-Fanelli, A.; Ipata, P.L.; Fasella, P. On the Distribution and Transformation of Thiamine and Its Phosphoric Esters in Biological Material. Biochem. Biophys. Res. Commun. 1961, 4, 23-27. [CrossRef]

23. Bettendorff, L.; Wins, P. Thiamine Derivatives in Excitable Tissues: Metabolism, Deficiency and Neurodegenerative Diseases. Recent Res. Devel. Neurochem. 1999, 2, 37-62.

24. Bettendorff, L. The Compartmentation of Phosphorylated Thiamine Derivatives in Cultured Neuroblastoma Cells. Biochim. Biophys Acta 1994, 1222, 7-14. [CrossRef]

25. Bettendorff, L.; Wins, P.; Lesourd, M. Subcellular Localization and Compartmentation of Thiamine Derivatives in Rat Brain. Biochim. Biophys. Acta 1994, 1222, 1-6. [CrossRef]

26. Gangolf, M.; Czerniecki, J.; Radermecker, M.; Detry, O.; Nisolle, M.; Jouan, C.; Martin, D.; Chantraine, F.; Lakaye, B.; Wins, P.; et al. Thiamine Status in Humans and Content of Phosphorylated Thiamine Derivatives in Biopsies and Cultured Cells. PLoS ONE 2010, 5, e13616. [CrossRef] [PubMed]

27. Matsuda, T.; Tonomura, H.; Baba, A.; Iwata, H. Tissue Difference in Cellular Localization of Thiamine Phosphate Esters. Comp. Biochem. Physiol. B 1989, 94, 405-409. [CrossRef]

28. Lakaye, B.; Wirtzfeld, B.; Wins, P.; Grisar, T.; Bettendorff, L. Thiamine Triphosphate, a New Signal Required for Optimal Growth of Escherichia coli during Amino Acid Starvation. J. Biol. Chem. 2004, 279, 17142-17147. [CrossRef] [PubMed]

29. Hofmann, M.; Loubéry, S.; Fitzpatrick, T.B. On the Nature of Thiamine Triphosphate in Arabidopsis. Plant Direct 2020, 4, e00258. [CrossRef]

30. Chernikevich, I.P.; Luchko, V.; Voskoboev, A.I.; Ostrovsky, Y.M. Purification and Properties of ATP:Thiamine Diphosphate Phosphotransferase from Brewer's Yeast. Biokhimiya 1984, 49, 899-907.

31. Shikata, H.; Koyama, S.; Egi, Y.; Yamada, K.; Kawasaki, T. Cytosolic Adenylate Kinase Catalyzes the Synthesis of Thiamin Triphosphate from Thiamin Diphosphate. Biochem. Int. 1989, 18, 933-941. [PubMed]

32. Gangolf, M.; Wins, P.; Thiry, M.; El Moualij, B.; Bettendorff, L. Thiamine Triphosphate Synthesis in Rat Brain Occurs in Mitochondria and Is Coupled to the Respiratory Chain. J. Biol. Chem. 2010, 285, 583-594. [CrossRef]

33. Egi, Y.; Koyama, S.; Shikata, H.; Yamada, K.; Kawasaki, T. Content of Thiamin Phosphate Esters in Mammalian Tissues - an Extremely High Concentration of Thiamin Triphosphate in Pig Skeletal Muscle. Biochem. Int. 1986, 12, 385-390. [PubMed]

34. Brune, M.; Schumann, R.; Wittinghofer, F. Cloning and Sequencing of the Adenylate Kinase Gene (Adk) of Escherichia coli. Nucleic Acids Res. 1985, 13, 7139-7151. [CrossRef] [PubMed]

35. Gigliobianco, T.; Lakaye, B.; Makarchikov, A.F.; Wins, P.; Bettendorff, L. Adenylate Kinase-Independent Thiamine Triphosphate Accumulation under Severe Energy Stress in Escherichia coli. BMC Microbiol. 2008, 8, 16. [CrossRef] [PubMed]

36. Makarchikov, A.F.; Wins, P.; Janssen, E.; Wieringa, B.; Grisar, T.; Bettendorff, L. Adenylate Kinase 1 Knockout Mice Have Normal Thiamine Triphosphate Levels. Biochim. Biophys. Acta 2002, 1592, 117-121. [CrossRef]

37. Gigliobianco, T.; Gangolf, M.; Lakaye, B.; Pirson, B.; von Ballmoos, C.; Wins, P.; Bettendorff, L. An Alternative Role of FoF1-ATP Synthase in Escherichia coli: Synthesis of Thiamine Triphosphate. Sci. Rep. 2013, 3, 1071. [CrossRef]

38. Miyoshi, K.; Egi, Y.; Shioda, T.; Kawasaki, T. Evidence for in Vivo Synthesis of Thiamin Triphosphate by Cytosolic Adenylate Kinase in Chicken Skeletal Muscle. J. Biochem. Tokyo 1990, 108, 267-270. [CrossRef]

39. Eder, L.; Dunant, Y. Thiamine and Cholinergic Transmission in the Electric Organ of Torpedo. I. Cellular Localization and Functional Changes of Thiamine and Thiamine Phosphate Esters. J. Neurochem. 1980, 35, 1278-1286. [CrossRef]

40. Bettendorff, L.; Michel-Cahay, C.; Grandfils, C.; De Rycker, C.; Schoffeniels, E. Thiamine Triphosphate and Membrane-Associated Thiamine Phosphatases in the Electric Organ of Electrophorus Electricus. J. Neurochem. 1987, 49, 495-502. [CrossRef]

41. Delvaux, D.; Kerff, F.; Murty, M.R.; Lakaye, B.; Czerniecki, J.; Kohn, G.; Wins, P.; Herman, R.; Gabelica, V.; Heuze, F.; et al. Structural Determinants of Specificity and Catalytic Mechanism in Mammalian 25-KDa Thiamine Triphosphatase. Biochim. Biophys. Acta 2013, 1830, 4513-4523. [CrossRef]

42. Szyniarowski, P.; Lakaye, B.; Czerniecki, J.; Makarchikov, A.F.; Wins, P.; Margineanu, I.; Coumans, B.; Grisar, T.; Bettendorff, L. Pig Tissues Express a Catalytically Inefficient 25-KDa Thiamine Triphosphatase: Insight in the Catalytic Mechanisms of This Enzyme. Biochim. Biophys. Acta 2005, 1725, 93-102. [CrossRef]

43. Zimatkina, T.I.; Chernikevich, I.P.; Zimatkin, S.M.; Deitrich, R.A. Thiamine Status in Liver and Brain of Rats Genetically Selected for Different Sensitivity to Hypnotic Effect of Alcohol [In Process Citation]. Alcohol. Clin. Exp. Res. 2000, 24, 1620-1624. [CrossRef]

44. Wu, C.-C.; Ekanem, T.I.; Phan, N.N.; Loan, D.T.T.; Hou, S.-Y.; Lee, K.-H.; Wang, C.-Y. Gene Signatures and Prognostic Analyses of the Tob/BTG Pituitary Tumor-Transforming Gene (PTTG) Family in Clinical Breast Cancer Patients. Int. J. Med. Sci. 2020, 17, 3112-3124. [CrossRef] [PubMed]

45. Liebecq, C.; Peters, R.A. The Toxicity of Fluoroacetate and the Tricarboxylic Acid Cycle. 1949. Biochim. Biophys. Acta 1989, 1000, 254-269. [PubMed]

46. Baba, T.; Ara, T.; Hasegawa, M.; Takai, Y.; Okumura, Y.; Baba, M.; Datsenko, K.A.; Tomita, M.; Wanner, B.L.; Mori, H. Construction of Escherichia coli K-12 in-Frame, Single-Gene Knockout Mutants: The Keio Collection. Mol. Syst. Biol. 2006, 2, 2006.0008. [CrossRef] 
47. Gigliobianco, T. Biosynthèse des Dérivés Triphosphorylés de la Thiamine Chez Escherichia coli. Ph.D. Thesis, University of Liège, Liège, Belgium, 2012.

48. Armingol, E.; Tobar, E.; Cabrera, R. Understanding the Impact of the Cofactor Swapping of Isocitrate Dehydrogenase over the Growth Phenotype of Escherichia coli on Acetate by Using Constraint-Based Modeling. PLoS ONE 2018, 13, e0196182. [CrossRef]

49. Bettendorff, L.; Schoffeniels, E.; Naquet, R.; Silva-Barrat, C.; Riche, D.; Menini, C. Phosphorylated Thiamine Derivatives and Cortical Activity in the Baboon Papio Papio: Effect of Intermittent Light Stimulation. J. Neurochem. 1989, 53, 80-87. [CrossRef]

50. Yamashita, H.; Zhang, Y.X.; Nakamura, S. The Effects of Thiamin and Its Phosphate Esters on Dopamine Release in the Rat Striatum. Neurosci. Lett. 1993, 158, 229-231. [CrossRef]

51. Nghiêm, H.O.; Bettendorff, L.; Changeux, J.P. Specific Phosphorylation of Torpedo 43K Rapsyn by Endogenous Kinase(s) with Thiamine Triphosphate as the Phosphate Donor. FASEB J. 2000, 14, 543-554. [CrossRef] [PubMed]

52. Cooper, J.R.; Pincus, J.H. The Role of Thiamine in Nervous Tissue. Neurochem. Res. 1979, 4, 223-239. [CrossRef]

53. Bettendorff, L.; Peeters, M.; Wins, P.; Schoffeniels, E. Metabolism of Thiamine Triphosphate in Rat Brain: Correlation with Chloride Permeability. J. Neurochem. 1993, 60, 423-434. [CrossRef]

54. Bettendorff, L.; Hennuy, B.; De Clerck, A.; Wins, P. Chloride Permeability of Rat Brain Membrane Vesicles Correlates with Thiamine Triphosphate Content. Brain Res. 1994, 652, 157-160. [CrossRef]

55. Bettendorff, L.; Hennuy, B.; Wins, P.; Schoffeniels, E. Thiamin and Derivatives as Modulators of Rat Brain Chloride Channels. Neuroscience 1993, 52, 1009-1017. [CrossRef]

56. Bettendorff, L.; Kolb, H.A.; Schoffeniels, E. Thiamine Triphosphate Activates an Anion Channel of Large Unit Conductance in Neuroblastoma Cells. J. Membr. Biol. 1993, 136, 281-288. [CrossRef] [PubMed]

57. Sabirov, R.Z.; Islam, M.R.; Okada, T.; Merzlyak, P.G.; Kurbannazarova, R.S.; Tsiferova, N.A.; Okada, Y. The ATP-Releasing Maxi-Cl Channel: Its Identity, Molecular Partners and Physiological/Pathophysiological Implications. Life Basel Switz. 2021, 11, 509. [CrossRef]

58. Fitzpatrick, T.B.; Chapman, L.M. The Importance of Thiamine (Vitamin B1) in Plant Health: From Crop Yield to Biofortification. J. Biol. Chem. 2020, 295, 12002-12013. [CrossRef]

59. Murai, A.; Katsura, E. Thiamine Triphosphatase Activity of Myosin and Accelerating Effect of Thiamine Di- and Tri-Phosphates on Superprecipitation of Actomyosin. J. Nutr. Sci. Vitaminol. Tokyo 1975, 21, 169-181. [CrossRef]

60. Shioda, T.; Kawasaki, T. Thiamin Triphosphate Does Not Affect Contraction of Skinned Fibers. J. Nutr. Sci. Vitaminol. Tokyo 1992, 38, 529-533. [CrossRef]

61. Barchi, R.L.; Braun, P.E. A Membrane-Associated Thiamine Triphosphatase from Rat Brain. Properties of the Enzyme. J. Biol. Chem. 1972, 247, 7668-7673. [CrossRef]

62. Barchi, R.L. Membrane Thiamine Triphosphatase from Rat Brain: Inhibition by ATP and ADP. J. Neurochem. 1976, 26, 715-720. [CrossRef] [PubMed]

63. Bettendorff, L.; Wins, P.; Schoffeniels, E. Thiamine Triphosphatase from Electrophorus Electric Organ Is Anion-Dependent and Irreversibly Inhibited by 4,4'-Diisothiocyanostilbene-2,2'disulfonic Acid. Biochem. Biophys. Res. Commun. 1988, 154, 942-947. [CrossRef]

64. Bettendorff, L.; Grandfils, C.; Wins, P.; Schoffeniels, E. Thiamine Triphosphatase in the Membranes of the Main Electric Organ of Electrophorus Electricus: Substrate-Enzyme Interactions. J. Neurochem. 1989, 53, 738-746. [CrossRef] [PubMed]

65. Matsuda, T.; Tonomura, H.; Baba, A.; Iwata, H. Membrane-Associated Thiamine Triphosphatase in Rat Skeletal Muscle. Int J. Biochem. 1991, 23, 1111-1114. [PubMed]

66. Bettendorff, L.; Longree, I.; Wins, P.; Schoffeniels, E. Solubilization of Thiamine Triphosphatase from the Electric Organ of Electrophorus Electricus. Biochim. Biophys. Acta 1991, 1073, 69-76. [CrossRef]

67. Kolas, I.K.; Makarchikov, A.F. Properties of chicken liver membrane-associated thiamine triphosphatase. Ukr. Biochem. J. 2015, 87, 37-46. [CrossRef] [PubMed]

68. Sidorova, A.A.; Stepanenko, S.P.; Parkhomenko Iu, M. Characteristics of Thiamine Triphosphatase from Neural Cells Plasma Membranes. Ukr. Biokhim. Zh. 2009, 81, 57-65.

69. Parkhomenko, I.M.; Strokina, A.A.; Pilipchuk, S.; Stepanenko, S.P.; Chekhovskaia, L.I.; Donchenko, G.V. Existence of Two Different Active Sites on Thiamine Binding Protein in Plasma Membranes of Synaptosomes. Ukr. Biokhim. Zh. 2010, 82, 34-41.

70. Hashitani, Y.; Cooper, J.R. The Partial Purification of Thiamine Triphosphatase from Rat Brain. J. Biol. Chem. 1972, 247, 2117-2119. [CrossRef]

71. Rusina, I.M.; Makarchikov, A.F. Thiamine Triphosphatase Activity in Mammalian Mitochondria. Ukr. Biokhim. Zh. 2003, 75, 63-68.

72. Makarchikov, A.F.; Chernikevich, I.P. Purification and Characterization of Thiamine Triphosphatase from Bovine Brain. Biochim. Biophys. Acta 1992, 1117, 326-332. [CrossRef]

73. Lakaye, B.; Makarchikov, A.F.; Antunes, A.F.; Zorzi, W.; Coumans, B.; De Pauw, E.; Wins, P.; Grisar, T.; Bettendorff, L. Molecular Characterization of a Specific Thiamine Triphosphatase Widely Expressed in Mammalian Tissues. J. Biol. Chem. 2002, 277, 13771-13777. [CrossRef]

74. Lakaye, B.; Verlaet, M.; Dubail, J.; Czerniecki, J.; Bontems, S.; Makarchikov, A.F.; Wins, P.; Piette, J.; Grisar, T.; Bettendorff, L. Expression of 25 KDa Thiamine Triphosphatase in Rodent Tissues Using Quantitative PCR and Characterization of Its MRNA. Int. J. Biochem. Cell Biol. 2004, 36, 2032-2041. [CrossRef] [PubMed] 
75. Iyer, L.M.; Aravind, L. The Catalytic Domains of Thiamine Triphosphatase and CyaB-like Adenylyl Cyclase Define a Novel Superfamily of Domains That Bind Organic Phosphates. BMC Genom. 2002, 3, 33. [CrossRef]

76. Gong, C.; Smith, P.; Shuman, S. Structure-Function Analysis of Plasmodium RNA Triphosphatase and Description of a Triphosphate Tunnel Metalloenzyme Superfamily That Includes Cet1-like RNA Triphosphatases and CYTH Proteins. RNA 2006, 12, 1468-1474. [CrossRef] [PubMed]

77. Delvaux, D.; Murty, M.R.; Gabelica, V.; Lakaye, B.; Lunin, V.V.; Skarina, T.; Onopriyenko, O.; Kohn, G.; Wins, P.; De Pauw, E.; et al. A Specific Inorganic Triphosphatase from Nitrosomonas Europaea: Structure and Catalytic Mechanism. J. Biol. Chem. 2011, 286, 34023-34035. [CrossRef] [PubMed]

78. Kohn, G.; Delvaux, D.; Lakaye, B.; Servais, A.C.; Scholer, G.; Fillet, M.; Elias, B.; Derochette, J.M.; Crommen, J.; Wins, P.; et al. High Inorganic Triphosphatase Activities in Bacteria and Mammalian Cells: Identification of the Enzymes Involved. PLoS ONE 2012, 7, e43879.

79. Moeder, W.; Garcia-Petit, C.; Ung, H.; Fucile, G.; Samuel, M.A.; Christendat, D.; Yoshioka, K. Crystal Structure and Biochemical Analyses Reveal That the Arabidopsis Triphosphate Tunnel Metalloenzyme, AtTTM3, Is a Tripolyphosphatase and Is Involved in Root Development. Plant J. 2013, 76, 615-626. [CrossRef] [PubMed]

80. Kleinboelting, S.; Miehling, J.; Steegborn, C. Crystal Structure and Enzymatic Characterization of the Putative Adenylyl Cyclase HpAC1 from Hippeastrum Reveal Dominant Triphosphatase Activity. J. Struct. Biol. 2020, 212, 107649. [CrossRef]

81. Ung, H.; Karia, P.; Ebine, K.; Ueda, T.; Yoshioka, K.; Moeder, W. Triphosphate Tunnel Metalloenzyme Function in Senescence Highlights a Biological Diversification of This Protein Superfamily. Plant Physiol. 2017, 175, 473-485. [CrossRef]

82. Vogt, M.S.; Ngouoko Nguepbeu, R.R.; Mohr, M.K.F.; Albers, S.-V.; Essen, L.-O.; Banerjee, A. The Archaeal Triphosphate Tunnel Metalloenzyme SaTTM Defines Structural Determinants for the Diverse Activities in the CYTH Protein Family. J. Biol. Chem. 2021, 297, 100820. [CrossRef]

83. Bettendorff, L.; Wins, P. Thiamine Triphosphatase and the CYTH Superfamily of Proteins. FEBS J. 2013, 280, 6443-6455. [CrossRef]

84. Świeżawska, B.; Duszyn, M.; Kwiatkowski, M.; Jaworski, K.; Pawełek, A.; Szmidt-Jaworska, A. Brachypodium Distachyon Triphosphate Tunnel Metalloenzyme 3 Is Both a Triphosphatase and an Adenylyl Cyclase Upregulated by Mechanical Wounding. FEBS Lett. 2020, 594, 1101-1111. [CrossRef] [PubMed]

85. Makarchikov, A.F. The rate of molecular evolution of mammalian soluble thiamine triphosphatase. Ukr. Biokhim. Zh. 1999 2009, 81, 26-42. [PubMed]

86. Song, J.; Bettendorff, L.; Tonelli, M.; Markley, J.L. Structural Basis for the Catalytic Mechanism of Mammalian 25-KDa Thiamine Triphosphatase. J. Biol. Chem. 2008, 283, 10939-10948. [CrossRef] [PubMed]

87. Ung, H.; Moeder, W.; Yoshioka, K. Arabidopsis Triphosphate Tunnel Metalloenzyme2 Is a Negative Regulator of the Salicylic Acid-Mediated Feedback Amplification Loop for Defense Responses. Plant Physiol. 2014, 166, 1009-1021. [CrossRef]

88. Sehnal, D.; Bittrich, S.; Deshpande, M.; Svobodová, R.; Berka, K.; Bazgier, V.; Velankar, S.; Burley, S.K.; Koča, J.; Rose, A.S. Mol* Viewer: Modern Web App for 3D Visualization and Analysis of Large Biomolecular Structures. Nucleic Acids Res. 2021, 49, W431-W437. [CrossRef]

89. Czerniecki, J.; Chanas, G.; Verlaet, M.; Bettendorff, L.; Makarchikov, A.F.; Leprince, P.; Wins, P.; Grisar, T.; Lakaye, B. Neuronal Localization of the 25-KDa Specific Thiamine Triphosphatase in Rodent Brain. Neuroscience 2004, 125, 833-840. [CrossRef]

90. Kovacevic, Z.; Fu, D.; Richardson, D.R. The Iron-Regulated Metastasis Suppressor, Ndrg-1: Identification of Novel Molecular Targets. Biochim. Biophys. Acta 2008, 1783, 1981-1992. [CrossRef]

91. Suryo Rahmanto, Y.; Dunn, L.; Richardson, D. Identification of Distinct Changes in Gene Expression after Modulation of Melanoma Tumor Antigen P97 (Melanotransferrin) in Multiple Models in Vitro and in Vivo. Carcinogenesis 2007, 26, $2172-2183$. [CrossRef]

92. Terkelsen, T.; Pernemalm, M.; Gromov, P.; Børresen-Dale, A.-L.; Krogh, A.; Haakensen, V.D.; Lethiö, J.; Papaleo, E.; Gromova, I. High-Throughput Proteomics of Breast Cancer Interstitial Fluid: Identification of Tumor Subtype-Specific Serologically Relevant Biomarkers. Mol. Oncol. 2021, 15, 429-461. [CrossRef]

93. Linster, C.L.; Van Schaftingen, E.; Hanson, A.D. Metabolite Damage and Its Repair or Pre-Emption. Nat. Chem. Biol. 2013, 9, 72-80. [CrossRef] [PubMed]

94. Kohn, G. Metabolic Significance of Inorganic Triphosphate, Thiamine Triphosphate and Their Hydrolyzing Enzyme; University of Liege: Liege, Belgium, 2015.

95. Bettendorff, L.; Peeters, M.; Jouan, C.; Wins, P.; Schoffeniels, E. Determination of Thiamin and Its Phosphate Esters in Cultured Neurons and Astrocytes Using an Ion-Pair Reversed-Phase High-Performance Liquid Chromatographic Method. Anal. Biochem. 1991, 198, 52-59. [CrossRef]

96. Frédérich, M.; Delvaux, D.; Gigliobianco, T.; Gangolf, M.; Dive, G.; Mazzucchelli, G.; Elias, B.; De Pauw, E.; Angenot, L.; Wins, P.; et al. Thiaminylated Adenine Nucleotides. Chemical Synthesis, Structural Characterization and Natural Occurrence. FEBS J. 2009, 276, 3256-3268. [CrossRef] [PubMed]

97. Monteverde, D.R.; Gómez-Consarnau, L.; Suffridge, C.; Sañudo-Wilhelmy, S.A. Life's Utilization of B Vitamins on Early Earth. Geobiology 2017, 15, 3-18. [CrossRef] [PubMed]

98. Makarchikov, A.F.; Saroka, T.V.; Kudyrka, T.G.; Kolas, I.K.; Luchko, T.A.; Rusina, I.M.; Gurinovich, V.A. Adenosine Thiamine Triphosphate and Adenosine Thiamine Triphosphate Hydrolase Activity in Animal Tissues. Ukr Biochem. J. 2018, 90 , 52-63. [CrossRef] 
99. Hofer, A.; Marques, E.; Kieliger, N.; Gatter, S.-K.N.; Jordi, S.; Ferrari, E.; Hofmann, M.; Fitzpatrick, T.B.; Hottiger, M.O.; Jessen, H.J. Chemoselective Dimerization of Phosphates. Org. Lett. 2016, 18, 3222-3225. [CrossRef] [PubMed]

100. Möhler, M.; Höfer, K.; Jäschke, A. Synthesis of 5'-Thiamine-Capped RNA. Molecules 2020, 25, 5492. [CrossRef]

101. Makarchikov, A.F.; Brans, A.; Bettendorff, L. Thiamine Diphosphate Adenylyl Transferase from E. Coli: Functional Characterization of the Enzyme Synthesizing Adenosine Thiamine Triphosphate. BMC Biochem. 2007, 8, 17. [CrossRef]

102. Hofmann, M. On the Role of Triphosphorylated Thiamine Compounds in Arabidopsis Thaliana. Ph.D. Thesis, Université de Genève, Genève, Switzerland, 2019.

103. Gigliobianco, T.; Lakaye, B.; Wins, P.; El Moualij, B.; Zorzi, W.; Bettendorff, L. Adenosine Thiamine Triphosphate Accumulates in Escherichia coli Cells in Response to Specific Conditions of Metabolic Stress. BMC Microbiol. 2010, 10, 148. [CrossRef] [PubMed]

104. Tanaka, T.; Yamamoto, D.; Sato, T.; Tanaka, S.; Usui, K.; Manabe, M.; Aoki, Y.; Iwashima, Y.; Saito, Y.; Mino, Y.; et al. Adenosine Thiamine Triphosphate (AThTP) Inhibits Poly(ADP-Ribose) Polymerase-1 (PARP-1) Activity. J. Nutr. Sci. Vitaminol. Tokyo 2011, 57, 192-196. [CrossRef] 